\title{
"Yuk Cegah Virus Corona!" Edukasi Pencegahan Corona Melalui Buku Interaktif Anak-Anak
}

\author{
*Alifia Ananda Putri ${ }^{1}$, Yeni Arumdani ${ }^{2}$, Muhammad Fathi Fadhil Fauzi Rizal ${ }^{3}$ \\ Fakultas Seni Rupa dan Desain, Institut Seni Indonesia Surakarta1,2,3
}

\begin{abstract}
Artikel History

Dikirim: 15 April 2021

Revisi : 30 April 2021

Diterima: 5 Juni 2021

Corona Virus or COVID-19 was first discovered in December 2019 in Wuhan, China. On January 30, 2020, WHO announced that this epidemic was a global health emergency, spreading so quickly that it reached various countries including Indonesia. Covid-19 had weakened and paralyzed various sectors in Indonesia and even all countries. One of the impacts is in the world of education. Since the implementation of the online system, there have been many pros and cons that have occurred among the community as well as challenges that must be faced with the existence of this distance learning system (PJJ). Early childhood education is undeniably affected by COVID19. The research method uses empirical methods by collecting data sources from libraries and journals that have been there before. The results of the study concluded that the making of an interactive book "Come on, Prevent Coronavirus!" is a type of busy book in which this book can provide various activities for children so that they will not be bored in digesting the learning material.
\end{abstract}

Keyword: Covid-19, Impact, Education, Interactive Book

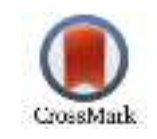

\begin{abstract}
Abstrak
Bahasa Jawa, salah satu dari 300 lebih bahasa yang ada di Indonesia. Untuk memahami dibalik peninggalan nenek moyang kita, peran aksara Jawan cukup signifikan pengaruhnya sehingga penting untuk dipelajari dan dipahami. Ketertarikan anak usia dini pada kebudayaan Indonesia pada saat ini mulai kurang dan semakin lama dapat menyebabkan kebudayaan Indonesia ditinggalkan. Rendahnya tingkat kemampuan membaca dan menulis aksara Jawa dikarenakan oleh beberapa faktor yaitu, minat, guru, metode pembelajaran, serta sarana dan prasarana media pembelajaran. Menerapkan metode pembelajaran aksara Jawa sejak usia dini dengan menggunakan media permainan puzzle ini diharapkan generasi mendatang dapat menguasainya dan dapat menjaga kelestarian budaya-budaya yang dimiliki oleh negara tercinta ini. Metode penelitian yang dipilih yaitu kualitatif deskriptif dengan mengumpulkan data melalui proses studi literatur yang mana pengumpulan data berasal dari buku buku dan dokumen terkait dengan bahasan artikel ini.
\end{abstract}

Kata Kunci : Aksara jawa, Puzzle, Pembelajaran, Belajar, Metode

Corresponding author.

E-mail: Email: alifiaanandaputeri@gmail.com

This is an open-access article under the CC-BY-SA license 


\section{PENGANTAR}

OVID-19 merupakan penyakit infeksi yang menggangu saluran pernafasan, dimana gejalanya berupa flu ringan sampai sesak nafas hingga menyebabkan kematian. Penyebaran virus ini sangat cepat melalui kontak fisik manusia yang ditularkan melalui mulut, hidung, serta mata. Corona Virus atau COVID-19 pertama kali ditemukan pada bulan Desember 2019 di Wuhan, Cina. Pada tanggal 30 Januari 2020 WHO mengumumkan bahwa wabah ini menjadi masalah darurat kesehatan global, penyebaranya begitu cepat sampai ke berbagai negara termasuk Indonesia. Virus COVID-19 membawa dampak besar bagi berbagai sektor salah satunya sektor pendidikan. Untuk memutus rantai penyebaran virus ini, Mendikbud pada tanggal 9 Maret 2020 mengeluarkan Surat Edaran No 3 tahun 2020 tentang Pencegahan COVID-19 pada Satuan Pendidikan: Surat Edaran Sekjen Kemendikbud No 36603/ A.A5/OT/ 2020 pada 15 Maret 2020. Kemudaian UNESCO mencatat, sebanyak 290 juta pelajar diseluruh dunia terkena dampak virus COVID-19. Dikutip dari laman resmi UNNESCO, terhitung sejak Maret 2020 UNESCO menetapkan untuk menutup sementara sekolah-sekolah guna mengurangi penyebaran COVID-19. Mendikbud (Menteri Pendidikan dan Kebudayaan ) juga memutuskan untuk menerapkan kebijakan kegiatan belajar mengajar (KBM) dari tingkat dini sampai mahasiswa untuk melaksanakan KBM di rumah masingmasing dan dilakukan secara daring.

Sejak diberlakukanya sistem daring, banyak pro dan kontra yang terjadi dikalangan masyarakat, dari permasalahan sinyal yang buruk, kuota internet, tidak adanya sarana pendukung pembelajaran hingga para orang tua yang dilema besar akan biaya sekolah. Pendidikan anak usia dini tidak dapat dipungkiri juga terkena immbas dari COVID-19 ini. Seperti yang dijelaskan dalam kajian quantum learning oleh Porter \& Hernacki (1999:4-8), semua anak harus hidup dengan bahagia, maka dari itu pembelajaran harus menyenangkan. Jika anak bahagia maka otak limbiknya akan terbuka dam mudah dalam menangkap informasi secara maksimal, sedangkan jika anak tidak bahagia, maka otak limbiknya akan susah untuk menerima informasi yang disampaikan (Prima, 2018: 44-45). menurut Yuliawan (2018: 47) orang tua sebagai pelatih dirumah yang menyediakan fasilitas dan sarana belajar mengajar, tidak selalu sesuai yang diharapkan. Orang tua yang mebgajar anak dirumah belum tentu memahami psikologi anak, cara mengatasi situasi hati anak dan tidak menentu, cara menstimulus anak dengan baik terutama cara mengajar anak dengan baik yang sesuai dengan tuntunan psikologi anak (Ulfah \& Na'imah 2020: 20-28). Berdasarkan hal tersebut penulis memiliki gagasan untuk menciptakan buku alternatif pendidikan pencegahan corona bagi anak-anak. Buku ini berupa informasi dan langkah-langkah pencegahan virus corona, 
yang nantinya secara keseluruhan berisikan gambar ilustrasi sehingga anak-anak tertarik untuk membaca. Gagasan buku ini diberi judul “Ayo, Cegah Virus Corona!”.Tujuan yang ingin dicapai dalam gagasan ini yaitu menciptakan inovasi baru berupa pembelajaran mengenai COVID-19 dengan buku ilustrasi anak pada masa pandemi, merancang Buku “Ayo, Cegah Virus Corona" dalam bentuk bentuk fisik maupun non-fisik.

\section{PEMBAHASAN}

\section{A. Kondisi Kekinian Pencetus Gagasan}

Di Indonesia sendiri, diberlakukan kebijakan Pembatasan Sosial Berskala Besar (PSBB) untuk menekan penyebaran Virus Corona masih tetap berlansung hingga saat ini. Karena Indonesia sedang melakukan PSBB, maka semua kegiatan yang dilakukan di luar rumah harus dihentikan sampai pandemi ini mereda. Beberapa pemerintah daerah memutuskan menerapkan kebijakan untuk meliburkan siswa dan mulai menerapkan metode belajar dengan sistem daring (dalam jaringan) atau online. Kebijakan pemerintah ini mulai efektif diberlakukan di beberapa wilayah provinsi di Indonesia pada hari Senin, 16 Maret 2020. Dikarenakan hal tersebut, guru dituntut dapat mendesain media pembelajaran sebagai inovasi dengan memanfaatkan media daring (online).

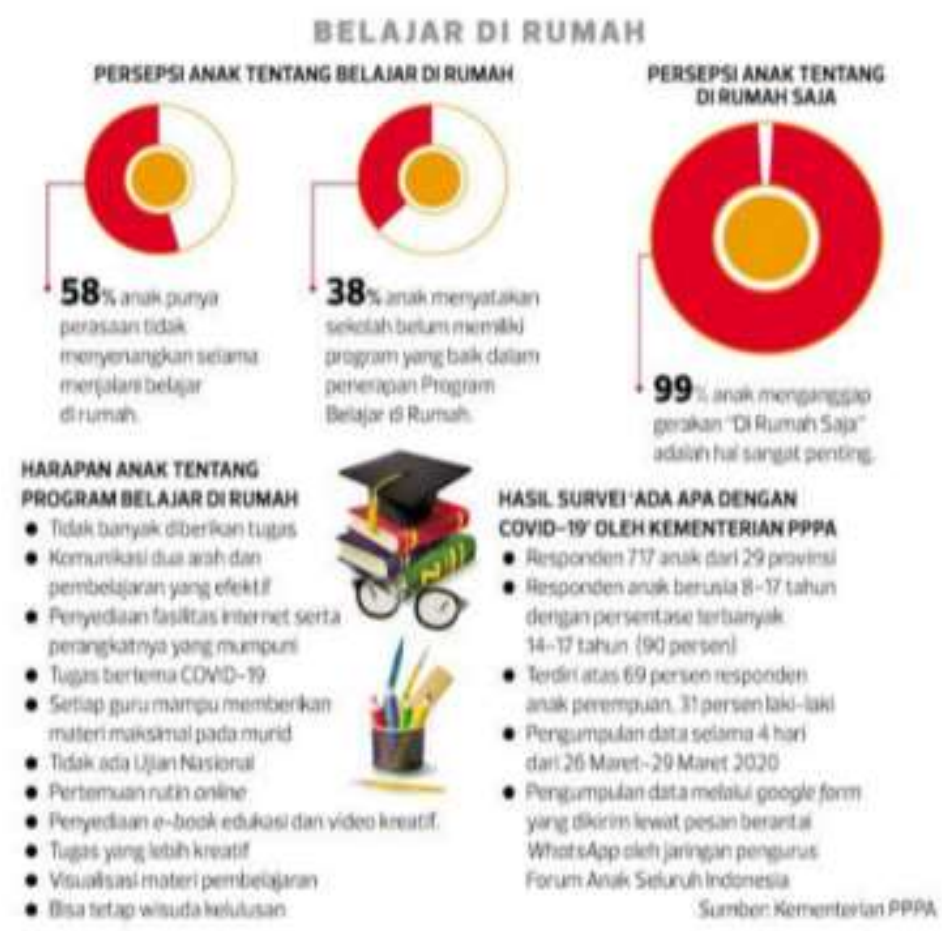

Gambar 1: Grafik Kementerian PPPA Persepsi Anak tentang Belajar di Rumah (Sumber: Kementerian PPPA) 
Sistem pembelajaran yang baru menciptakan permasalahan yang baru sehingga hal ini pun perlu perhatian. Permasalahan ini bisa menyerang anak anak dalam periode emas. Periode emas sendiri adalah durasi waktu (0-8 tahun) di mana terjadi perkembangan massa otak sebanyak 70-80\%. Apabila periode emas Anak dilalui dengan cara yang tepat, dirinya akan menjadi pribadi yang mumpuni dan siap untuk menghadapi persaingan global di masa depan. Namun dengan adanya pembelajaran daring bisa mengancam perkembangan anak. Pembelajaran daring melalui aplikasi videocall atau chat membuat anak cenderung malas dan bosan dikarenakan penyampaian yang monoton atau ketidaknyamanan anak belajar dengan sistem baru ini. Fakta ini pun diperkuat dengan grafik yang disediakan oleh kementrian PPPA perihal persepsi anak tentang belajar di rumah. Dalam grafik ini, lebih dari setengah responden menyatakan bahwa mereka bosan belajar melalui daring. Hal tersebut menunjukkan bahwa anak dalam periode emas bisa terancam perkembangannya dikarenakan pembelajaran daring ini. Oleh karena itu, perlu dibentuk sebuah sarana untuk menyemangati anak-anak supaya lebih giat lagi dalam pembelajaran, karena kita tidak akan tahu kapan tepatnya pandemi ini akan berakhir.

\section{B. Solusi yang Pernah Ditawarkan atau Diterapkan sebelumnya untuk Memperbaiki}

\section{Keadaan Pencetus Gagasan}

Sampai saat ini sudah banyak solusi yang dilakukan oleh pemerintah, contohnya adalah Kementerian Pendidikan dan Kebudayaan (Kemendikbud) bekerja sama juga dengan salah satu stasiun televisi nasional yaitu TVRI untuk membentuk salah satu sarana televisi edukasi. Konten dari Televisi edukasi ini sendiri telah didesain sedimikian rupa agar sesuai dengan umur penontonnya agar nyaman untuk dinikmati. Namun efek yang ditimbulkan dari program ini kurang maksimal, karena sensor kognitif anak tidak bisa berkembang secara maksimal. Pada pembelajaran normal, anak dengan periode emas terbiasa diberi pemlajaran untuk melatih sensor kognitif di kelas agar tetap merasa fun dan senang di kelas sehingga perpindahan sistem pembelajaran mereka dari normal ke daring dirasa seperti perubahan yang sangat besar dan mereka tidak terbiasa dengan kondisi seperti ini. Maka dari itu anak akan cepat bosan.

\section{Seberapa Jauh Kondisi Kekinian Pencetus Gagasan dapat Diperbaiki melalui Gagasan yang Diajukan dan Prediksi Hasil jika Gagasan Tersebut Diimplementasikan}


Dalam upaya menjaga semangat anak dalam mengikuti pembelajaran anak, diperlukan inovasi yang menarik. Inovasi buku interaktif dijadikan jalan penyelesaiannya. Buku interaktif ini berjudul "Yuk Cegah Corona!” dengan bertemakan edukasi pencegahan Corona yang sesuai untuk anak anak dalam umur periode emas. Buku interaktif ini adalah buku interaktif jenis busy book yang mana buku ini bisa memberikan berbagai aktivitas untuk anak sehinngga ia tidak bosan dalam pembelajaran. Buku ini disediakan dengan tema edukasi pencegahan Corona agar anak bisa lebih mengerti apa itu Corona dan bagaimana pencegahannya. Buku ini akan tersedia dalam berbagai aktivitas yang mana nantinya bisa dijadikan sebagai challenge pembelajaran yang seru untuk anak. Kelebihan dari buku ini antara lain:

1. Mencegah rasa bosan anak dalam belajar daring.

2. Meningkatkan sensor kognitif anak.

3. Meningkatkan hubungan anak dengan keluarga karena diperlukan bimbingan dengan keluarga dalam pengerjaan buku ini.

4. Tersedia dalam versi online dan versi cetak.

5. Memberikan edukasi mengenai Corona sehingga anak bisa mencegah diri dari corona.

6. Efektif dalam penyampaian pesan buku ke para pembaca.

7. Sistem busy book membuat anak lebih aktif dalam pembelajaran. 8. Sebagai media perkembangan masa emas anak.

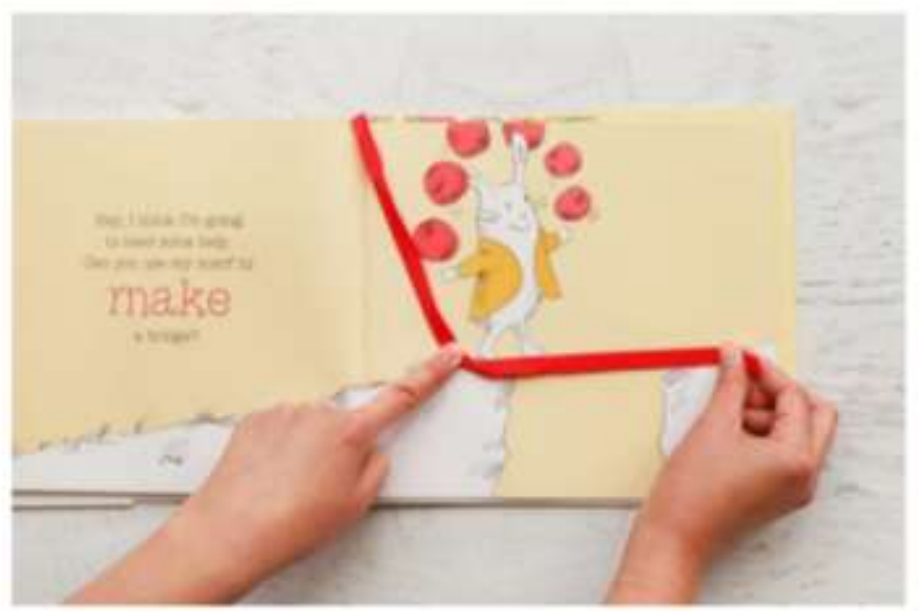

Gambar 2:. Contoh Buku interaktif (Sumber:

https://id.pinterest.com/pin/32158584825315060) 
Gambaran sistem buku interaktif ini kurang lebih akan seperti gambar di atas ini. Untuk buku ini sendiri akan berukuran A4 dengan fullcolor, tersedia dalam versi cetak dan online yang mana nantinya akan tersedia di platform seperti aplikasi perpustakaan nasional. Untuk buku ini sendiri akan menggunakan hardcover dan buku interaktif ini bersistem busy book yang mana nantinya terdapat beberapa tantangan yang bisa dikerjakan oleh anak agar ia bisa berinteraksi langsung menggunakan arahan dan petunjuk yang telah disampaikan dalam buku. Lalu, untuk rancangan desain cover dari buku interaktif "Yuk Cegah Virus Corona!" akan berisi ilustrasi seorang anak laki-laki yang menggunakan masker dan terlindungi dari Corona yang sedang cemberut lalu disekelilingnya terdapat perisai yang menganalogikan seperti pelindungnya. Warna yang dipilih dakam cover ini cenderung kea arah soft. Cover nya digambar seperti dibawah ini;

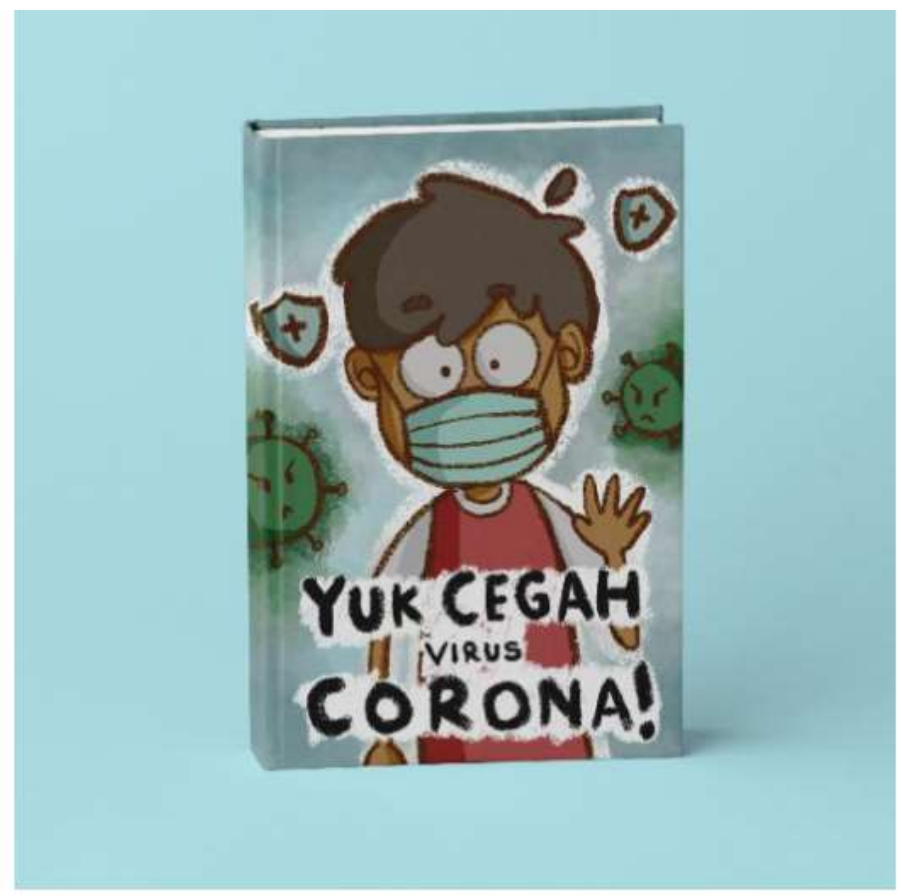

Gambar 3: Desain cover dari buku interaktif "Yuk Cegah Virus Corona!" (Sumber: Alifia Ananda Putri, 2020)

Beberapa konten buku ini antara lain:

1. Edukasi tentang Virus Corona dan cara pencegahannya.

2. Kegiatan membuat kolase dari salah satu ilustrasi yang disediakan.

3. Membuka beberapa konten Lift-the-flap.

4. Kegiatan mencari karakter yang ditentukan dalam ilustrasi detail yang menyebar.

5. Kegiatan mewarnai ilutrasi hitam putih yang disediakan dalam buku. 
6. Merakit benda do-it-yourself dengan bahan bahan yang telah disediakan dalam buku.

7. Beberapa permainan tekstur yang disediakan dalam buku.

8. Disediakan stiker yang mana ditempelkan pada halaman tertentu. Konten yang kami sebutkan diatas akan kami desain sedimikian rupa agar sesuai dengan minat anak anak. Dan pengerjaan buku ini akan memperlukan pengawasan dan pembimbingan anak agar mendapatkan hasil yang maksimal untuk perkembangan anak.

\section{Pihak-pihak yang Dipertimbangkan dapat Membantu Mengimplementasikan} Gagasan dan Uraian Peran atau Kontribusi Masing-masingnya.

Agar gagasan Buku interaktif "Yuk Cegah Corona!" dapat terealisasikan, maka pihakpihak yang diharapkan dapat membantu program ini supaya bisa terlaksana antara lain: 1. Pemerintah Daerah 2. Kementrian Pendidikan dan Kebudayaan 3. Semua staf sekolah Orang tua 5. Mahasiswa 6. Masyarakat

E. Langkah-langkah Strategis yang Harus Dilakukan untuk Mengimplementasikan Gagasan sehingga Tujuan atau Perbaikan yang Diharapkan dapat Tercapai

Gagasan sehingga Tujuan atau Perbaikan yang Diharapkan dapat Tercapai Langkah-langkah strategis yang perlu direncanakan dengan matang agar gagasan ini dapat teralisasikan dengan baik adalah: 1. Memberitahukan ide gagasan kepada kemendikbud dan pemerintahan daerah agar mendapatkan izin dalam produksi dan menjadi salah satu rekomendasi alternatif dalam pembelajaran daring anak. 2 . Mengembangkan kerja sama dengan pihak pihak yang berkemampuan mengerjakannya dan diikuti dengan proses konsultasi dari produk. 3. Menggerakan pihak-pihak yang terlibat dalam gagasan ini agar proses pelaksaan gagasan ini berjalan. 4. Proses pembuatan produk. 5. Sosialisasi sistem pembelajaran baru terhadap masyarakat. 6 . Melakukan evaluasi dari trial dan error, diikuti juga dengan monitoring dan pembelajaran dari pelaksanaan gagasan ini. Kesulitan yagn terjadi selama proses pelaksanaan gagasan ini bisa menjadi model untuk sistem kedepannya.

\section{KESIMPULAN}

Selama pandemi Covid-19 berlangsung, sistem pembelajaran menjadi terhambat. Sistem pembelajaran yang baru membuat anak-anak mudah bosan selama pembelajaran daring dan ini bisa berimbas pada perkembangan masa emas anak. Gagasan yang diajukan 
adalah Buku interaktif berjudul "Yuk Cegah Corona!" dengan bertemakan edukasi pencegahan Corona yang sesuai untuk anak anak dalam umur periode emas. Buku interaktif ini adalah buku interaktif jenis busy book yang mana buku ini bisa memberikan berbagai aktivitas untuk anak sehinngga ia tidak bosan dalam pembelajaran. Buku ini disediakan dengan tema edukasi pencegahan Corona agar anak bisa lebih mengerti apa itu Corona dan bagaimana pencegahannya. Buku ini akan menggunakan hardcover berukuran A4 fullcolor dan berisi ilustrasi menarik sehingga dapat menarik perhatian anak. Buku ini akan tersedia dalam berbagai aktivitas yang mana nantinya bisa dijadikan sebagai challenge pembelajaran yang seru untuk anak.

Apabila gagasan ini diimplementasikan diharapkan hasil yang dieproleh berupa; 1. Mencegah rasa bosan anak dalam belajar daring. 2. Meningkatkan sensor kognitif dan perkembangan masa emas anak. 3. Meningkatkan hubungan anak dengan keluarga karena diperlukan bimbingan dengan keluarga dalam pengerjaan buku ini. 4. Memberikan edukasi mengenai Corona sehingga anak bisa mencegah diri dari corona. 5. Membuat anak lebih aktif dalam pembelajaran dengan sistem busy book.

\section{DAFTAR PUSTAKA}

Ayuni, Despa, et al. "Kesiapan Guru TK Menghadapi Pembelajaran Daring Masa Pandemi Covid-19." Jurnal Obsesi: Jurnal Pendidikan Anak Usia Dini, vol. 5, no. 1, 2020, p. 414., doi:10.31004/obsesi.v5i1.579.

Halauwet, Bernando. Kontribusi UNESCO Dalam Penerapan SDG 4 Di Indonesia Terhadap Permasalahan Pendidikan Indonesia, 2018, pp. 1-17., doi:http:// repository.unpar.ac.id/handle/123456789/6371.

Hartono, Tirza Amelia, et al. "Perancangan Buku Interaktif Dalam Meningkatkan 'SelfEsteem' Sebagai Upaya Pencegahan 'Bullying' Pada Anak Usia 7-9 Tahun." DeKaVe, vol. 10, no. 1, 2017, p. 14., doi:10.24821/dkv.v10i1.1770.

Jazariyah, Jazariyah. "Signifikansi Brain Based Learning Pendidikan Anak Usia Dini." Nadwa, vol. 11, no. 1, 2017, p. 01., doi:10.21580/nw.2017.11.1.982.

Su'ud, F. M. (2017). PENGEMBANGAN KETERAMPILAN SOSIAL ANAK USIA DINI Analisis Psikologi Pendidikan Islam. Journal Al-Manar, 6(2).

Syafrida, S., \& Hartati, R. (2020). "Bersama melawan virus covid 19 di Indonesia." SALAM: Jurnal Sosial dan Budaya Syar-i, 7(6), 495-508.

Ulfa, Mutia, and Na'imah Na'imah. "Peran Keluarga Dalam Konsep Psikologi Perkembangan Anak Usia Dini." Aulad : Journal on Early Childhood, vol. 3, no. 1, 2020, pp. 20-28., doi:10.31004/aulad.v3i1.45. 
Wiresti, R. D. (2020). “Analisis Dampak Work From Home pada Anak Usia Dini di Masa Pandemi Covid-19." Jurnal Obsesi: Jurnal Pendidikan Anak Usia Dini, 5(1), 641653.

Wulandari, Hesti, and Edi Purwanta. "Pencapaian Perkembangan Anak Usia Dini Di Taman Kanak-Kanak Selama Pembelajaran Daring Di Masa Pandemi Covid-19." Jurnal Obsesi : Jurnal Pendidikan Anak Usia Dini, vol. 5, no. 1, 2020, p. 452., doi:10.31004/obsesi.v5i1.626.

Zaharah, Z., Kirilova, G. I., \& Windarti, A. (2020). Impact of corona virus outbreak towards teaching and learning activities in Indonesia. SALAM: Jurnal Sosial dan Budaya Syar-i, 7(3), 